\title{
Correlation between ischemia-modified albumin and Ranson score in acute pancreatitis
}

\author{
Cem Emir Güldoğan, M.D., ${ }^{1}$ Murat Özgür Kılıç, M.D.,' İlhan Balamir, M.D., ${ }^{2}$ \\ Mesut Tez, M.D., ${ }^{1}$ Turan Turhan, M.D. ${ }^{2}$ \\ 1'Department of General Surgery, Numune Training and Research Hospital, Ankara-Turkey \\ ${ }^{2}$ Department of Biochemistry, Numune Training and Research Hospital, Ankara-Turkey
}

\begin{abstract}
BACKGROUND: Although Ranson score is the most commonly used prognostic model in the severity of acute pancreatitis (AP), ischemia-modified albumin (IMA) has been reported as a novel biomarker of various ischemia-based diseases in recent years. The aim of the present study is to investigate the correlation between Ranson score and IMA in patients with AP.
\end{abstract}

METHODS: Forty-three patients with AP were included in the study. All patients were classified as mild and severe AP. Plasma IMA level was measured after diagnosis and before treatment. The correlation between IMA level and amylase level, Ranson score, and disease severity was evaluated.

RESULTS: Twenty-nine (67.4\%) patients were diagnosed as mild AP; the remaining 14 (32.6\%) patients had moderately severe or severe form of disease, and were classified as severe AP. There was no significant difference in the IMA levels between the patient groups $(p=0.737)$. No correlation between IMA levels and amylase levels $(p=0.470)$, Ranson score $(p=0.664)$, and disease severity $(p=0.74 I)$ was found.

CONCLUSION: According to the results from the study, IMA does not seem as a useful marker in earlier prediction of disease severity in AP. Despite important disadvantages, Ranson score still indicates the disease severity more accurately.

Keywords: Acute pancreatitis, ischemia-modified albumin, disease severity.

\section{INTRODUCTION}

Acute pancreatitis (AP) is among the most common causes of acute abdominal emergencies in the world. Although most of the patients with AP have mild disease, approximately 15\%-20\% cases develop severe or necrotizing form of AP. It is well known that AP, particularly severe form, is associated with increased morbidity and mortality rates. Therefore, determining disease severity within the first hours after hospital admission is of great importance for both treatment planning and decreasing the morbidity and mortality.

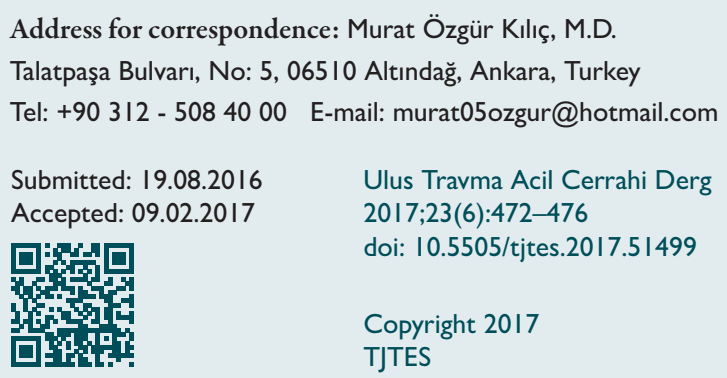

To date, many single-parameter and multi-parameter indicators have been reported to predict AP severity. Among those, Ranson criteria are the most widely used grading model; however, the need of many complex parameters and $48 \mathrm{~h}$ after admission to obtain a basic predictive score are its main limitations. In this respect, ischemia-modified albumin (IMA), a well-known biomarker of ischemia-based diseases such as stroke, acute mesenteric ischemia, acute pulmonary embolism, and acute coronary syndrome, may be considered as a novel predictor AP severity. ${ }^{[1-4]}$ Apart from being an ischemic marker, IMA has been also reported to be an indicator of oxidative stress. ${ }^{[5]}$ Although the main pathogenesis of AP is self-digestion of the organ by the abnormal activation of digestive enzymes, it was also shown that free oxygen radicals and cytokines have important roles in pancreatic damage and disease course. ${ }^{[6]}$

In this study, we aimed to determine whether serum IMA can be used as a novel and alternative indicator for predicting AP severity. 


\section{MATERIALS AND METHODS}

\section{Patients and Study Design}

Forty-three patients diagnosed with AP between December 2015 and April 2016 were included in this prospective clinical study. Patients with diabetes mellitus, chronic renal/hepatic failure, and cirrhosis as well as those aged $<18$ years were excluded from the study. The following criteria were used for the diagnosis of AP: acute onset of abdominal pain, typical physical examination findings, at least three-fold increase in plasma amylase level, and sonographic and/or tomographic confirmation of AP.

Plasma IMA level was measured after AP diagnosis and before treatment. Albumin cobalt binding calorimetric assay, previously described by Bar-Or et al.," ${ }^{[7]}$ was used for IMA measurements, and the results were provided in absorbance unit (ABSU). A formula (serum albumin concentration of the patient/median serum albumin concentration of the study population) $\times$ IMA ABSU value was used to eliminate the effect of albumin on IMA, and hence to obtain the corrected IMA.

All patients were classified as mild and severe AP, according to the Atlanta criteria based on the presence of organ failure for $>48 \mathrm{~h}$ and/or local complications. ${ }^{[8]}$ The criteria of organ failure were as follows: shock (systolic blood pressure $<90$ $\mathrm{mmHg}$ ), renal failure (serum creatinine level $>2 \mathrm{mg} / \mathrm{dL}$ after rehydration or hemodialysis), or pulmonary insufficiency (arterial PO2 $<60 \mathrm{mmHg}$ at room air or the need for mechanical ventilation). Ranson score was calculated using data in the first $24 \mathrm{~h}$ and after $48 \mathrm{~h}$ of admission.
Institutional Ethics Committee of Numune Training and Research Hospital approved this study. Written informed consent was obtained from all patients.

\section{Statistical Analysis}

Statistical analyses were performed using SPSS 17.0 (SPSS Inc., Chicago, Illinois). Kolmogorov-Smirnov test was used to assess the normality of data distribution. The variables were presented as mean \pm standard deviation (SD), median and interquartile range (IQ), or number and percentage unless otherwise specified. Chi-square test or Fisher exact test were used to compare categorical data, and Mann-Whitney U-test was used for the comparison of continuous variables. Correlations of IMA with amylase level, Ranson score, and disease severity were analyzed by Spearman's correlation coefficient. A p value of $<0.05$ was considered statistically significant.

\section{RESULTS}

A total of 43 patients with biliary AP were included in the study. There were 17 (39.5\%) males and 26 (60.5\%) females, with a mean age of $63.6(22-90)$ years. The median length of hospital stay was 6.I (3-12) days, and no mortality was observed during this period.

A total of 29 (67.4\%) patients were diagnosed as mild AP. The remaining $14(32.6 \%)$ patients had moderately severe or severe form of disease, and were classified as severe AP. The patients who had severe form of AP were older than those with mild AP $(p=0.020)$. Ranson score was also higher in patients with severe AP than in those with mild disease $(p=0.0 \mathrm{II})$. The mean IMA level was 0.626+0.II (0.379-0.947) ABSU.

Table I. The comparison of clinical characteristics, laboratory findings, and Ranson scores of the two groups

\begin{tabular}{|c|c|c|c|}
\hline Parameters & Patients with mild AP $(n=29)$ & Patients with severe AP $(n=14)$ & $\mathbf{p}$ \\
\hline Age (year, mean $\pm S D$ ) & $56.13 \pm 15.5(22-88)$ & $79.3 \pm 9.2(57-90)$ & 0.020 \\
\hline Female/Male & $16 / 13$ & $10 / 4$ & 0.343 \\
\hline White blood cell $\left(10000 / \mathrm{mm}^{3}\right)$ & $10900(9050-14500)$ & $11300(7850-13150)$ & 0.534 \\
\hline Glucose (mg/dL) & $124(105-179)$ & 140.5 (| | $8.7-172)$ & 0.795 \\
\hline Blood urea (mg/dL) & $29(22-38)$ & $51.5(41.2-66)$ & $<0.001$ \\
\hline Serum creatinine (mg/dL) & $0.85(0.76-0.97)$ & I.2(0.8-।.7) & 0.007 \\
\hline Serum albumin (g/dL) & $3.6(3.4-3.8)$ & $3.2(3-3.7)$ & 0.031 \\
\hline Aspartate aminotransferase (U/L) & $176(110-299)$ & $181(55-360)$ & 0.826 \\
\hline Alanine aminotransferase (U/L) & $185(106-324)$ & $159(54-262)$ & 0.422 \\
\hline Total bilirubin (mg/dL) & I.4 (0.7-3.I) & $1.7(I-5.4)$ & 0.254 \\
\hline Direct bilirubin (mg/dL) & $1.2(0.4-3)$ & $0.8(0.5-3.6)$ & 0.835 \\
\hline Lactate dehydrogenase & $303(223-445)$ & $301(225-548)$ & 0.959 \\
\hline Amylase (U/L) & 1327 (460-2872) & 1917 (793-2535) & 0.468 \\
\hline Ranson score (Interquartile range) & $0(0-2)$ & $I(I-2)$ & 0.011 \\
\hline Ischemia-modified albumin (Absorbance unit) & $0.621 \pm 0.107$ & $0.639 \pm 0.125$ & 0.737 \\
\hline
\end{tabular}

AP: Acute pancreatitis; SD: Standard deviation. 


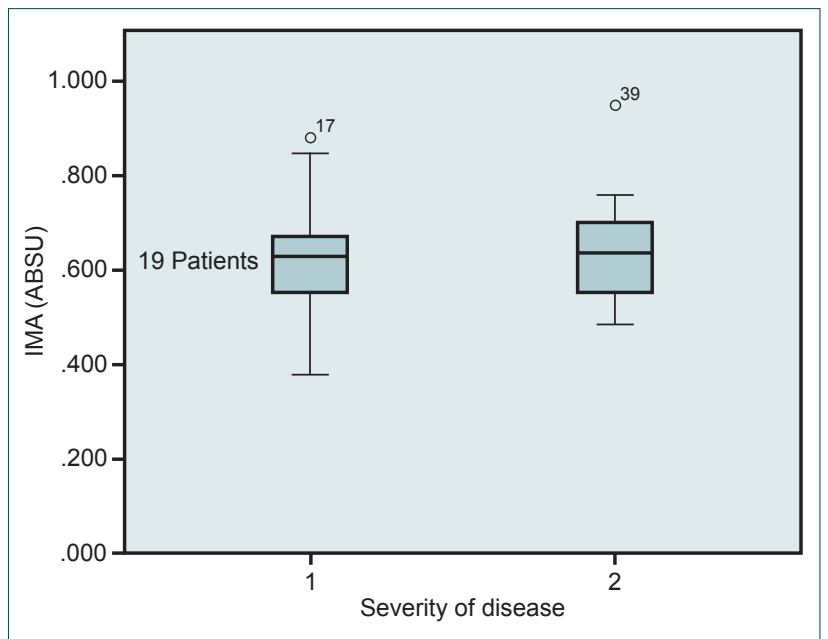

Figure 1. Ischemia-modified albumin (IMA) levels in patients with mild AP (1) and severe AP (2) $(0.621+0.107$ ABSU vs. 0.639+0.125 ABSU, $p=0.737$ ).

There was no significant difference in the IMA levels between the patients with mild AP and patients with severe form of disease $(p=0.737)$. The comparison of clinical characteristics, laboratory findings, and Ranson scores of the patients with mild AP and those with severe AP are presented in Table I.

The correlation between IMA level and amylase level, Ranson score, and disease severity (according to the Atlanta classification) was statistically evaluated. It was found that there was no correlation between IMA levels and amylase levels in the whole study population ( $r h o=+0.1$ I6, $p=0.470$ ). IMA was also not found to be correlated with Ranson score (rho $=-0.070$, $p=0.664)$. Similarly, no correlation was observed between IMA level and the disease severity $(r h o=0.053, p=0.74 I)($ Fig. I ).

\section{DISCUSSION}

Despite recent advances in diagnostic algorithms, critical care conditions, and other therapeutic approaches, AP, especially severe form of the disease, is still a dangerous disease with a mortality rate of $10 \%-20 \%{ }^{[9]}$ Approximately half of the deaths are related to multiple organ failure within the first week of the attack while septic complications are mainly responsible for the delayed mortality. Because of the high morbidity and mortality rates in AP, many scoring systems, laboratory tests, and radiological methods have been recommended to estimate the clinical disease course. Some of those grading systems including Ranson, ${ }^{[10]}$ Bedside Severity Index of AP (BISAP), ${ }^{[1]}$ and Imrie/Glasgow ${ }^{[12]}$ include parameters specific to AP whereas others, such as Acute Physiologic and Chronic Health Evaluation System (APACHE) ${ }^{[13]}$ and the Mortality Probability Models (MPM) $\|^{\left[{ }^{[14]}\right.}$ scores, are not specific to AP, and are widely used in all critically ill patients.

Apart from the complicated scoring systems, single biochemical markers such as C-reactive protein, procalcitonin, red cell distribution width, and interleukins have also been reported as promising predictors of AP severity. ${ }^{[15-17]}$ However, none of those provide an accurate prediction of disease severity, and thus are not widely used in routine practice. In this regard, IMA, a well-known marker for various ischemic-based diseases, may be considered as a novel and alternative predictor of disease severity considering that poor antioxidant status has been shown to be associated with progression of complications in $\mathrm{AP}^{[18,19]}$ It is known that various ischemic stressors are released from hypoxic tissues, and modify $\mathrm{N}$-terminal amino acids of circulating albumin to a different subtype called as IMA. ${ }^{[20]}$ This biochemical marker has been shown to play important roles in various hypoxic conditions, especially in ischemic heart disease. ${ }^{[2,4,21]}$ Although the pathogenesis of AP is multifactorial, an increasing number of studies have focused on the relationship between the oxidative stress status and AP ${ }^{[19,22]}$ Oxidative stress is primarily related to excessive production of reactive oxygen metabolites, which can cause damage in pancreatic cells. Free oxygen radicals are also considered to be involved in pancreatic edema and necrosis processes. ${ }^{[23,24]}$ Free oxygen radicals modify the metal binding terminals of human albumin. Therefore, the production of IMA is directly related to the production of free oxygen radicals. ${ }^{[25]}$ In addition, IMA level raises within a few minutes after tissue injury caused by free oxygen radicals, and returns to normal serum level after 6-12 h.

To date, the diagnostic role of IMA in various acute abdominal emergencies has been studied in a number of clinical studies. ${ }^{[2,26,27]}$ In one of those, serum levels of oxidative stress markers including IMA were found to be higher in patients with acute appendicitis than in healthy individuals. However, the authors found no correlation between the pathological extent of acute appendicitis and oxidative stress markers. [26] In another study, plasma IMA level was found to be significantly higher in acute mesenteric ischemia in comparison to the nonoccluded group, suggesting that IMA might have a diagnostic value in acute thromboembolic occlusion of mesenteric vessels. ${ }^{[2]}$

In the literature, there are only two studies on the association between IMA and AP. ${ }^{[19,28]}$ One of those was an experimental study conducted in rats, which aimed to determine the potential role of IMA in AP. ${ }^{[28]}$ Plasma IMA level was found to be significantly higher in rats with AP than in healthy rats. It was also shown that IMA was strongly correlated with serum amylase level, indicating that IMA could be considered as a novel diagnostic marker in AP. Moreover, the authors reported IMA as an additional marker to monitor inflammation during AP. The other study was conducted in patients with mild biliary and/or nonbiliary AP, and aimed to investigate the potential diagnostic role of oxidative status with using various oxidative stress parameters including IMA. ${ }^{[19]}$ The primary outcome of the study was that IMA was significantly elevated in patients with AP in comparison to healthy cases. The authors also showed a positive correlation between IMA and amylase and lipase levels, similar to the study by Topalo- 
glu et al. ${ }^{[28]}$ All those findings obtained from the two studies indicated the diagnostic IMA level in AP. However, the predictive IMA level was not clearly investigated. It is well known that the estimation of disease severity is important in AP management, considering the risk of dangerous complications. In contrast to those studies, the primary aim of the present study was to investigate the prognostic value of IMA in patients with AP. Therefore, there was no control group consisting of healthy patients. In addition, we found no significant association between IMA levels and amylase levels. With regard to this point, it should be stated here that all patients, except one, had a plasma IMA level $>0.400$ ABSU, which is generally considered as a reference level for ischemia. ${ }^{[29]}$ In the present study, IMA did not also show a correlation with both Ranson score and the Atlanta classification for predicting disease course. In our opinion, our work is the first report on this topic. It should be also noted that the sample size in both the previous studies was lower than that in our study. Consequently, all the findings obtained from the present study showed that IMA does not have any prognostic and predictive value in AP.

This study has some limitations. First, the sample size was small, and the majority of patients had Ranson score $<4$, making the statistical analysis difficult. Second, the measurement of IMA was not repeated after the treatment because the study mainly focused on the predictive value of IMA. Therefore, the effect of IMA in the clinical progress of patients was not evaluated.

In conclusion, this study is the first report on the prognostic role of IMA in patients with AP. According to the results from the present study, IMA does not seem to be a useful marker in earlier prediction of disease severity in patients with AP. However, the results should be confirmed by larger cohort studies. Despite important disadvantages, Ranson score more accurately indicates disease severity in patients with AP.

\section{Acknowledgments}

This research did not receive any specific grant from funding agencies in the public, commercial, or not-for-profit sectors.

\section{Competing Interests}

The authors report no proprietary or commercial interest in any product mentioned or concept discussed in this article.

\section{Conflict of interest: None declared.}

\section{REFERENCES}

1. Abboud H, Labreuche J, Meseguer E, Lavallee PC, Simon O, Olivot $\mathrm{JM}$, et al. Ischemia-modified albumin in acute stroke. Cerebrovasc Dis 2007;23:216-20. [CrossRef]

2. Gunduz A, Turedi S, Mentese A, Karahan SC, Hos G, Tatli O, et al. Isch- emia-modified albumin in the diagnosis of acute mesenteric ischemia: a preliminary study. Am J Emerg Med 2008;26:202-5. [CrossRef]

3. Kaya Z, Kayrak M, Gul EE, Altunbaş G, Toker A, Kiyici M, et al. The Role of Ischemia Modified Albumin in Acute Pulmonary Embolism. Heart Views 2014;15:106-10. [CrossRef]

4. Bhakthavatsala Reddy C, Cyriac C, Desle HB. Role of "Ischemia Modified Albumin" (IMA) in acute coronary syndromes. Indian Heart J 2014;66:656. [CrossRef]

5. Duarte MM, Rocha JB, Moresco RN, Duarte T, Da Cruz IB, Loro VL, et al. Association between ischemia-modified albumin, lipids and inflammation biomarkers in patients with hypercholesterolemia. Clin Biochem 2009;42:666-71. [CrossRef]

6. Closa D. Free radicals and acute pancreatitis: much ado about ... something. Free Radic Res 2013;47:934-40. [CrossRef]

7. Bar-Or D, Lau E, Winkler JV. A novel assay for cobalt-albumin binding and its potential as a marker for myocardial ischemia: a preliminary report. J Emerg Med 2000;19:311-5. [CrossRef]

8. Banks PA, Bollen TL, Dervenis C, Gooszen HG, Johnson CD, Sarr MG, et al. Classification of acute pancreatitis-2012: revision of the Atlanta classification and definitions by international consensus. Gut 2013;62:102-11. [CrossRef]

9. Maheshwari R, Subramanian RM. Severe Acute Pancreatitis and Necrotizing Pancreatitis. Crit Care Clin 2016;32:279-90. [CrossRef]

10. Ranson JH. The timing of biliary surgery in AP. Ann Surg 1979;189:65463. [CrossRef]

11. Wu BU, Johannes RS, Sun X, Tabak Y, Conwell DL, Banks PA. The early prediction of mortality in AP: a large population-based study. Gut 2008;57:1698-703. [CrossRef]

12. Leese T, Shaw D. Comparison of three Glasgow multifactor prognostic scoring systems in AP. Br J Surg 1988;75:460-2. [CrossRef]

13. Knaus WA, Draper EA, Wagner DP, Zimmerman JE. APACHE II: a severity of disease classification system. Crit Care Med 1985;13:818-29.

14. Lemeshow S, Teres D, Klar J, Avrunin JS, Gehlbach SH, Rapoport J. Mortality Probability Models (MPM II) based on an international cohort of intensive care unit patients. JAMA 1993;270:2478-86. [CrossRef]

15. Rau B, Steinbach G, Gansauge F, Mayer JM, Grunert A, Beger HG. The potential role of procalcitonin and interleukin 8 in the prediction of infected necrosis in AP. Gut 1997;41:832-40. [CrossRef]

16. Stimac D, Fisic E, Milic S, Bilic-Zulle L, Peric R. Prognostic values of IL-6, IL-8, and IL-10 in AP. J Clin Gastroenterol 2006;40:209-12.

17. Senol K, Saylam B, Kocaay F, Tez M. Red cell distribution width as a predictor of mortality in AP. Am J Emerg Med 2013;31:687-9. [CrossRef]

18. Abu-Zidan FM, Bonham MJ, Windsor JA. Severity of acute pancreatitis: a multivariate analysis of oxidative stress markers and modified Glasgow criteria. Br J Surg 2000;87:1019-23. [CrossRef]

19. Baser H, Can U, Karasoy D, Ay AS, Baser S, Yerlikaya FH, et al. Evaluation of oxidant/anti-oxidants status in patients with mild acute pancreatitis. Acta Gastroenterol.Belg 2016;79:23-8.

20. Dekker MS, Mosterd A, van 't Hof AW, Hoes AW. Novel biochemical markers in suspected acute coronary syndrome: systematic review and critical appraisal. Heart 2010;96:1001-10. [CrossRef]

21. Uslu AU, Kucuk A, Balta S, Ozturk C, Arslan S, Tekin L, et al. The relation between ischemia modified albumin levels and carotid intima media thickness in patients with rheumatoid arthritis. Int J Rheum Dis 2016.

22. Winterbourn CC, Bonham MJ, Buss H, Abu-Zidan FM, Windsor JA. Elevated protein carbonyls as plasma markers of oxidative stres in acute pancreatitis. Pancreatology 2003;3:375-82. [CrossRef]

23. Scott P, Bruce C, Schofield D, Shiel N, Braganza JM, Mc Cloy RF. Vita- 
min C status in patients with acute pancreatitis. Br J Surg 1993;80:750-4.

24. Inoue $\mathrm{S}$, Kawanishi S. Oxidative DNA damage induced by simultaneous generation of nitric oxide and superoxide. FEBS Lett 1995;371:86-8.

25. Gidenne S, Ceppa F, Fontan E, Perrier F, Burnat P. Analytical performance of the albumin cobalt binding (ACB) test on the Cobas MIRA Plus analyzer. Clin Chem Lab Med 2004;42:455-61. [CrossRef]

26. Dumlu EG, Tokaç M, Bozkurt B, Yildirim MB, Ergin M, Yalcin A, et al. Correlation between the serum and tissue levels of oxidative stress markers and the extent of inflammation in acute appendicitis. Clinics
2014;69:677-82. [CrossRef]

27. Guven S, Kart C, Guvendag Guven ES, Cetin EC, Menteşe A. Is the measurement of serum ischemia-modified albumin the best test to diagnose ovarian torsion? Gynecol Obstet Invest 2015;79:269-75. [CrossRef]

28. Topaloglu N, Kucuk A, Tekin M, Yildirim S, Erbas M, Kiraz HA, et al. Serum Ischemia-Modified Albumin Levels in Experimental Model of Acute Pancreatitis. J Coll Physicians Surg Pak 2015;25:395-8.

29. Kadığlu H, Kaptanoğlu L. İskemik Modifiye Albüminin Acil Cerrahide Kullanımı. J Kartal TR 2012;23:106-9.

\section{ORİJİNAL ÇALIŞMA - ÖZET}

\section{Akut pankreatitte iskemi modifiye albümin ve Ranson skoru arasındaki korelasyon Dr. Cem Emir Güldoğan, ${ }^{1}$ Dr. Murat Özgür Kılıç, ${ }^{1}$ Dr. İlhan Balamir, ${ }^{2}$ Dr. Mesut Tez, ${ }^{1}$ Dr. Turan Turhan ${ }^{2}$}

${ }^{1}$ Numune Eğitim ve Araştırma Hastanesi, Genel Cerrahi Kliniği, Ankara

${ }^{2}$ Ankara Numune Eğitim ve Araştırma Hastanesi, Biyokimya Laboratuvarı, Ankara

AMAÇ: Ranson skoru akut pankreatitin (AP) şiddetinde en yaygın kullanılan prognostik model olmasına karşın, iskemi modifiye albümin (IMA) son yıllarda çeşitli iskemi temelli hastalıklar için yeni bir belirteç olarak bildirilmiştir. Amaç AP hastalarında Ranson skoru ve iMA arasındaki korelasyonu araştırmaktır.

GEREÇ VE YÖNTEM: Kırk üç AP hastası çalışmaya dahil edildi. Tüm hastalar hafif ve şiddetli AP olarak sınıflandırıldı. Plazma IMA seviyesi tanıdan sonra ve tedaviden öncesi ölçüldü. İskemi modifiye albümin düzeyi ile amilaz düzeyi, Ranson skoru ve hastalığın şiddeti arasındaki ilişki değerlendirildi.

BULGULAR: Yirmi dokuz (\%67.4) hastaya hafif AP tanısı konarken, 14 (\%32.6) hasta orta şiddetli veya şiddetli hastalık formuna sahipti ve şiddetli AP olarak sınılandırıldı. Hasta grupları arasında IMA düzeylerinde anlamlı bir fark yoktu ( $p=0.737)$. İskemi modifıye albümin düzeyleri ile amilaz düzeyleri ( $p=0.470)$, Ranson skoru $(p=0.664)$ ve hastalık şiddeti $(p=0.74 I)$ arasında korelasyon saptanmadı.

TARTIŞMA: Çalışmadan elde edilen sonuçlara göre, iMA AP'de hastalık şiddetinin erken tahmininde yararlı bir belirteç olarak görünmemektedir. Önemli dezavantajlarına rağmen, Ranson skoru hastalı̆̆ı şiddetini daha doğru göstermektedir. Anahtar sözcükler: Akut pankreatit; hastalık şiddeti; iskemi modifiye albümin.

Ulus Travma Acil Cerrahi Derg 2017;23(6):472-476 doi: 10.5505/tjtes.2017.5।499 